\title{
The effect of risedronate on osteogenic lineage is mediated by cyclooxygenase-2 gene upregulation
}

\author{
Maria Teresa Valenti', Sandro Giannini ${ }^{2}$, Luca Donatelli ${ }^{1}$, Mirko Zanatta ${ }^{1}$, Francesco Bertoldo ${ }^{1}$, Stefania Sella ${ }^{2}$, \\ Maria Teresa Vilei ${ }^{2}$, Elena Ossi ${ }^{2}$, Giuseppe Realdi ${ }^{2}$, Vincenzo Lo Cascio ${ }^{1}$, Luca Dalle Carbonare ${ }^{1 *}$
}

\begin{abstract}
Introduction: The purpose of this study was to evaluate the effects of risedronate (Ris) in the modulation of bone formation in rats with glucocorticoid (GC)-induced osteoporosis by histomorphometric, immunohistochemical and gene expression analyses.
\end{abstract}

Methods: We analyzed structure, turnover and microarchitecture, cyclooxygenase 2 (COX-2) levels and osteocyte apoptosis in 40 female rats divided as follows: 1) vehicle of methylprednisolone (vGC) + vehicle of risedronate

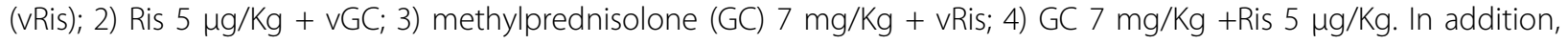
we evaluated cell proliferation and expression of COX-2 and bone alkaline phosphatase (b-ALP) genes in bone marrow cells and MLO-y4 osteocytes treated with Ris alone or in co-treatment with the selective COX-2 inhibitor NS-398 or with dexametasone.

Results: Ris reduced apoptosis induced by GC of osteocytes (41\% vs $86 \%, P<0.0001)$ and increased COX-2 expression with respect to controls (Immuno-Hystochemical Score (IHS): 8.75 vs 1.00, $P<0.0001$ ). These positive effects of Ris in bone formation were confirmed by in vitro data as the viability and expression of b-ALP gene in bone marrow cells resulted increased in a dose dependent manner.

Conclusions: These findings suggest a positive effect of Ris in bone formation and support the hypothesis that the up-regulation of COX-2 could be an additional mechanism of anabolic effect of Ris.

\section{Introduction}

Bisphosphonates (BPs), synthetic analogs of pyrophosphate, are the most effective inhibitors of bone resorption and are currently used in the treatment of several bone diseases. Their mechanism of action has been well described. They bind tightly to bone mineral surface, penetrate into osteoclasts and stimulate their apoptosis through the inhibition of the mevalonate pathway [1].

Recent findings suggest that bisphosphonates may also indirectly suppress bone resorption through their action on osteoblasts [2], and osteocytes [3], which could represent another target for these drugs.

Instead, it is not clear if BPs have also a beneficial influence on the bone formation process. Histomorphometric analysis in osteoporotic subjects indicates that BPs may increase the mean wall thickness and reduce

\footnotetext{
* Correspondence: luca.dallecarbonare@univr.it

'Clinic of Internal Medicine D, Department of Medicine - University of

Verona Piazzale L. Scuro, 10 - 37134 Verona, Italy

Full list of author information is available at the end of the article
}

the imbalance between formation and resorption at the basic multicellular unit (BMU) $[4,5]$, leading to a continuing increase in bone mineral density (BMD) even after a long period of treatment, as demonstrated in clinical studies [6].

They also control osteoblastic proliferation and differentiation $[7,8]$, modulate osteoblast production of extracellular matrix proteins, regulate the secretion of several cytokines and growth factors $[9,10]$ and enhance proliferation and maturation of bone marrow stromal cells to osteoblastic lineage [11]. Bisphosphonates are also able to prevent apoptosis of osteoblasts and osteocytes induced by glucocorticoid therapy [12]. It is well known that osteocytes are well differentiated osteoblasts regularly spaced throughout the mineralized matrix. They are believed to detect bone microdamage and to transmit signals leading to its repair $[13,14]$.

The disruption of the osteocyte network could compromise this mechanism, leading to accumulated microdamage and increased bone fragility. Such a defect in 
bone quality could account for the higher incidence of fractures and the disproportion between the significant increase in bone fragility and the relative small decrease of BMD observed, for example, in glucocorticoid induced osteoporosis [12,15].

In our previous histomorphometric study on glucocorticoid-induced osteoporosis [16] we found that rats treated with risedronate (Ris) showed increased trabecular number and thickness and decreased trabecular separation not only with respect to glucocorticoid treated rats but also with respect to controls. In addition, increased wall thickness, the end product of osteoblastic activity, was observed. In terms of turnover, rats treated with Ris showed a reduced activation frequency with an increased active Formation Period. All these findings suggest an effect of Ris on osteoblastic lineage and support the hypothesis of a neoformative activity of bisphosphonates.

The mechanism by which bisphosphonates stimulate osteoblasts is not yet completely elucidated. Giuliani et al. [10] reported that the anabolic effect of BPs was associated with the stimulation of b-FGF, while Mundy et al. demonstrated that the anabolic effect of statins, which influence the mevalonate pathway as BPs, was due to their stimulation of Bone Morphogenetic Protein-2 (BMP-2) [17]; BMP-2 gene expression was also upregulated during osteoblast maturation after BP treatment [18]. Von Knoch et al. showed that a cascade of osteoblast-related genes including $B M P-2$, cbfa-1, type 1 collagen and Bone Sialo-Proteins (BSP) were up regulated and significantly increased in bone marrow stromal cells after BP treatment [11]. The Osteoprotegerin/ Receptor Activator of Nuclear Factor $-\kappa \mathrm{B}$ Ligand (OPG/ RANKL) system is also influenced by BPs and may be related, at least in part, to the stimulatory effects of BPs on osteoblastic differentiation [2].

In addition, it has been shown that exogenous and endogenous prostaglandins (PGs) modulate both bone formation and resorption [19-23]. PGs are produced by cyclooxygenase (COX), which is a rate-limiting enzyme that converts arachidonic acid to PGs [24]. Three isoforms of COX are recognized: COX 1, which is constitutively expressed, COX-2, which is inducible by multiple factors and involved in PGs production during inflammation and other acute responses [25] and COX3 , which has recently been related to paracetamolinduced hypothermia and analgesia [26,27]. On the contrary, the inhibition of cyclooxygenase (COX) has been associated with decreased bone formation in vivo [28] and delayed experimental fracture healing [29].

Strontium ranelate, a new treatment for postmenopausal osteoporosis that exerts both antiresorptive and anabolic effects on bone, is able to influence prostaglandins metabolism. Strontium ranelate induces
COX-2 expression and promotes PGE2 production and activity in murine primary calvarian osteoblast trough ERK pathway [30]. It also increases osteoblastic differentiation and mineralization, acting on early osteoblastic precursors to induce COX-2 and PGE2 production [31].

Up to now, studies about the effects of BPs on cyclooxygenase are lacking. On the basis of these data, we hypothesized that BPs could upregulate COX-2 expression according to their putative anabolic effect on bone previously suggested by histomorphometric results. To verify this hypothesis, we studied the effect of Ris by evaluating histomorphometric parameters in rat tibiae and apoptosis and COX-2 expression in femur specimens in the presence or absence of a negative effect on osteoblastic/osteocytic lineage induced by glucocorticoids. To verify the presence of a direct stimulus of Ris on osteoblastic cells, we analysed in vitro the viability and $C O X-2$ gene expression in bone marrow stromal cells treated with Ris at different concentrations, in the presence and absence of NS-398, a selective COX-2 inhibitor [32]. In addition, to analyze the effects of bisphosphonates on osteogenic differentiation, we evaluated the mRNA expression of bone marker Alkaline Phosphatase $(b-A L P)$ on stromal cells treated with Ris at different concentrations. On the same model, we investigated a possible relationship between COX-2 pathway and osteogenic differentiation by analyzing mRNA $b$-ALP expression in presence or absence of COX-2 inhibitor.

\section{Materials and methods \\ Animals}

Forty six-month-old female Sprague-Dawley rats of approximately 200 to 300 g body weight were obtained from Charles River Italia (Calco, Italy). All rats were housed under similar conditions. They were fed a standard rodent diet containing $0.97 \%$ calcium, $0.85 \%$ phosphorus, 1,045 IU/Kg vitamin D3, 22.5\% protein, 5.5\% fat, $52 \%$ carbohydrate, and were given access to tap water ad libitum.

The animal procedures were approved by the local government authorities and were conducted in accord with accepted standards of humane animal care, as outlined in the Ethical Guidelines.

\section{Drugs}

Risedronate (Ris) in powder form was provided by Procter and Gamble Pharmaceuticals Inc. (Cincinnati, OH, USA). Ris was dissolved in deionized water and was administered at $5 \mu \mathrm{g} / \mathrm{Kg}$ subcutaneously (s.c.) three times a week. Methylprednisolone (GC, Solu-Medrol Pharmacia, Stockholm, Sweden)) was diluted in a sesame oil vehicle at a concentration of $7 \mathrm{mg} / \mathrm{kg}$. 


\section{Study protocol in vivo}

At the beginning of the study, rats were randomly divided into four groups (10 rats each) and treated s.c. three times a week as follows:

1. Control group: GC vehicle (vGC) + Ris vehicle (vRis);

2. Ris group: Ris $5 \mu \mathrm{g} / \mathrm{Kg}$ body weight $+\mathrm{vGC}$;

3. GC Group: GC $7 \mathrm{mg} / \mathrm{Kg}+\mathrm{vRis}$;

4. GC + Ris Group: GC $7 \mathrm{mg} / \mathrm{Kg}$ and Ris $5 \mu \mathrm{g} / \mathrm{Kg}$.

The rats were weighed once a week to adjust the drug dose to body weight. The study's experimental period lasted 30 days. To evaluate dynamic parameters of bone formation, the rats received double fluorochrome labeling with demeclocycline, $25 \mathrm{mg} / \mathrm{Kg}$ s.c. on Day -14 and -13 , and with calcein, $10 \mathrm{mg} / \mathrm{Kg}$ s.c. on Day -4 and -3 prior to sacrifice.

\section{Histomorphometry}

The right tibiae were removed, dissected free of soft tissue, and fixed in $70 \%$ reagent alcohol. The samples were embedded undecalcified in methyl-methacrylate resin (Merck 800590, Darmstadt, Germany).

Measurements were performed by means of an image analysis system consisting of an epifluorescent microscope (Leica DMR, Leica Microsystems, Wetzlar, Germany) connected to an analogic 3 CCD camera (Sony DXC 390P; Sony, Tokio, Japan) and a computer equipped with a specific software for histomorphometric analyses (Bone, Explora Nova, La Rochelle, France). The area analyzed was restricted to the trabecular bone of the secondary spongiosa area between 2 and $4 \mathrm{~mm}$ distal to the growth plate-metaphyseal junction [33].

Histomorphometric parameters are reported in accordance with the ASBMR Committee nomenclature [34].

Thickness results were adjusted for the obliquity of sections by multiplying by $\pi / 4$ [34].

\section{Immunohistochemical determination of COX-2 expression} Explants of left femora were fixed in $4 \%$ buffer formalin for 24 hours, decalcified with $0.5 \mathrm{~mol} / \mathrm{L}$ ethylendiaminetetraacetic acid, $\mathrm{pH} 8$, for 7 to 10 days, paraffin embedded, and cross sectioned ( $5 \mu \mathrm{m}$ thick) at three different levels. Goat Serum was purchased from Sigma-Aldrich Co. (St. Louis, MO, USA); Primary Antibody, rabbit anti-mouse cox-2, from NeoMarkers Inc. (Fremont, CA, USA); Secondary Antibody, goat anti-rabbit IgG-B, from SantaCruz Biotechnology Inc., Santa Cruz, CA, USA; ABC solution, Vectastain ABC kit, from Vector Laboratories Inc. (Burlingame, CA, USA); DAB solution, Liquid DAB Substrate Chromogen System, from DakoCytomation (Fort Collins, Colorado, USA). Immunohystochemistry was performed on paraffin-embebbed specimen sections, following the technique of Fortier et al. [35], with the same modification. Briefly, slides were stored in the stove at $60^{\circ} \mathrm{C}$ till paraffin loosed, and then were washed in xylene, followed by rehydration through graded ethanol washes. Permeabilization was performed by heating at $70^{\circ}$ in a humidified chamber, the sections were previously covered with $10 \mathrm{mM}$ citrate buffer, $\mathrm{pH}$ 6.0, followed by cooling at room temperature. The endogenous peroxidases were blocked by incubation in DI water $0.3 \% \mathrm{H} 2 \mathrm{O} 2$, and non-specific binding was prevented by incubation in PBS $10 \%$ Goat Serum. The first antibody (rabbit anti-mouse COX-2) was diluted 1:25 in PBS 10\% Goat Serum, and the slides were incubated overnight at $4^{\circ} \mathrm{C}$ in humidified chamber. Slides were then washed in $1 \%$ Triton PBS, following a second blocking step with PBS 10\% Goat Serum. Secondary biotinylated antibody (goat anti-rabbit IgG-B) was added at the dilution of 1:100. After 30 minutes of incubation at room temperature, sections were washed in PBS 1\% Triton $\mathrm{X}-100$ followed by only PBS, before staining by use of a Vectastain peroxidise standard ABC kit, and DAB solution, both according to the suppliers' protocol. Cells were then counterstained with haematoxylin and mounted with glycerol solution. For each sample, six random fields at $40 \times$ of magnification were analyzed by counting positive cells with respect to total cells. Results were expressed as an immunohistochemical score (IHS), based on the German Immunoreactive Score, which combines quantity and intensity values. The IHS is calculated by combining the percentage of immunoreactive cells (quantity score, \%) with an estimate of the staining intensity; quantity score: no staining is scored as $0 ; 1$ to $10 \%$ of cells stained scored as $1 ; 11$ to $50 \%$ as $2 ; 51$ to $80 \%$ as 3 ; and 81 to $100 \%$ as 4 ; staining intensity was rated on a scale of from 0 to 3 , with 0 being negative, 1 weak, 2 moderate, and 3 strong. The raw data were converted to IHS by multiplying the quantity and staining intensive score.

\section{Apoptosis}

Apoptotic nuclei in paraffined tissue were identified by Terminal deoxynucleotidyl Transferase-Biotin-dUTP nick end labeling (TUNEL) technique. The procedure was the one reported in the manufacturer's instruction (Roche, Mannheim, Germany). Apoptotic nuclei were identified by the red precipitate obtained by incubating the glass slides with $0.04 \% 3$-amino-9-ethyl- carbazole (AEC) in $50 \mathrm{mM}$ sodium citrate buffer, $\mathrm{pH} 5$ containing $0.015 \% \mathrm{H}_{2} \mathrm{O}_{2}$. The values were expressed as the percentage of TUNEL-position nuclei with respect to the total haematoxylin-stained nuclei. Six different fields with about 40 total cells for each sample were measured.

\section{Study protocol in vitro \\ Cell culture}

$\beta$-glycero-phosphate, $0.1 \mathrm{mM}$ L-ascorbic 2-phosphate and dexametasone were purchased from StemCell (StemCell Technologies, Vancouver, BC, Canada). 
Almost all other chemicals were from Sigma (St Louis, MO, USA). Other companies are specified in the text.

Bone marrow cells were obtained from 8 to 10 weekold Sprague-Dawley rats. The femurs were removed aseptically and dissected, the ends of bones were cut and the marrow was flushed out with DMEM by using a needle and syringe. The marrow was disperded gently by pipetting several times to obtain a single cell suspension and the cells were counted with a hemocytometer. Cells were seeded into $25 \mathrm{ml}$ cell culture flasks at a density of $1 \times 10^{6}$ cells $/ \mathrm{ml}$ and culture for $48 \mathrm{~h}$ at $37^{\circ} \mathrm{C}$ in a humidified atmosphere with $5 \% \mathrm{CO}_{2}$ in DMEM containing $2 \mathrm{mM} \mathrm{L}$ glutamine, $20 \%$ fetal bovine serum, $100 \mathrm{U} / \mathrm{ml}$ streptomycin and $100 \mu \mathrm{g} / \mathrm{ml}$ penicillin. After $48 \mathrm{~h}$, all nonadherent cells were removed and the adherent cells were grown for an additional period. At sub-confluence, cells were detached with trypsin and at the third passage the cells were plated in a 96-well cell culture plate or $25 \mathrm{ml}$ cell culture flasks at a density of $3.0 \times 10^{5}$ cells/ $\mathrm{ml}$. The cells were cultured in osteogenic differentiation medium consisting of DMEM with 10\% FBS supplemented with $10 \mathrm{mM} \beta$-glycero-phosphate and $0.1 \mathrm{mM}$ L-ascorbic 2-phosphate.

MLO-Y4 osteocytes, a cell line derived from mouse long bones (provided by Dr. L. F. Bonewald, University of Missouri, Kansas City, MO [36]), was cultured in minimum essential medium (-MEM) supplemented with $2.5 \%$ fetal bovine serum (FBS; Gibco, Grand Island, NY, USA), $2.5 \%$ calf serum (Gibco), $100 \mathrm{U} / \mathrm{ml}$ streptomycin and $100 \mu \mathrm{g} / \mathrm{ml}$ penicillin at $37^{\circ} \mathrm{C}$ and $5 \% \mathrm{CO}_{2}$ in air. The cells were cultured in osteogenic differentiation medium consisting of -MEM with $2.5 \%$ fetal bovine serum, $2.5 \%$ calf serum, $100 \mathrm{U} / \mathrm{ml}$ streptomycin and $100 \mu \mathrm{g} / \mathrm{ml}$ penicillin supplemented with $10 \mathrm{mM} \beta$ glycero-phosphate and $0.1 \mathrm{mM} \mathrm{L}$-ascorbic 2-phosphate.

The cultures were treated with Ris at concentrations ranging from 0.1 to $10 \mu \mathrm{M}$ with or without NS-398 (0.1 $\mu \mathrm{M})$, or with dexametasone $(1 \mu \mathrm{M})$ as specified in the figures, and controls were treated with vehicle (DMSO, $<0.1 \%)$.

\section{XTT assay}

Cell viability was evaluated by a colorimetric assay based on the reduction of the tetrazolium salt XTT [(sodium $3^{\mathrm{I}}$-(1-phenylamino-carbonyl-3,4-tetrazolium)-bis(4-methoxy-6-nitro)] benzene sulfonic acid hydrate) by mitochondrial dehydrogenase of viable cells to a formazan dye (Cell proliferation kit II - XTT Roche). Briefly, cells were cultivated in 96 microtitre plates in medium containing different concentrations of Ris with or without NS-398. After $72 \mathrm{~h}, 50 \mu \mathrm{l}$ XTT labeling mixture was added to each well and incubated at $37^{\circ} \mathrm{C}$ for $4 \mathrm{~h}$. The spectrophotometric absorbance of the samples was measured using a microtitre plate (ELISA) reader at a wavelength of $450 \mathrm{~nm}$.

\section{Total RNA extraction and reverse transcription}

Total RNA was extracted from each cell pellet using the RNAeasy minikit (Qiagen, Duesseldorf, Germany) with DNAse I treatment. The amount and purity of the RNA were checked by measuring the absorbance at 260 and $280 \mathrm{~nm}$, and where a ratio ranging from 1.8 to 2.0 was taken to be pure. First-strand cDNA was generated from $1 \mu \mathrm{g}$ of total RNA using the First Strand cDNA Synthesis Kit (GE Healthcare, Buckinghamshire, United Kingdom), with random hexamers, (GE Healthcare) according to the manufacturer's protocol. RT product was aliquoted in equal volumes and stored at $-80^{\circ} \mathrm{C}$.

\section{Real time RT-PCR}

mRNA quantification was analyzed by Relative Standard Curve Method (Chemistry guide Applied Biosystems (Foster City, CA, USA). PCR was performed in a total volume of $25 \mu \mathrm{l}$ containing $1 \times$ Taqman Universal PCR Master mix, no AmpErase UNG and $5 \mu \mathrm{l}$ of cDNA from each sample; pre-designed, Gene-specific primers and probe sets for each gene were obtained from Assay-onDemande Gene Expression Products (Rat (RN01483828m1, Cox2; RN01516028-m1, b-ALP; RN00667869-m1, $A C T b$ ) (mouse (Mm01307329-m1, Cox2; Mm01187117$\mathrm{m} 1, b-A L P ; A C T b$ human) Applied Biosystems). The Real Time amplifications included 10 minutes at $95^{\circ} \mathrm{C}$ (AmpliTaq Gold activation), followed by 40 cycles at $95^{\circ}$ $\mathrm{C}$ for 15 seconds and at $60^{\circ} \mathrm{C}$ for 1 minute. Thermocycling and signal detection were performed with $A B I$ Prism 7300 Sequence Detector (Applied Biosystems). Signals were detected according to the manufacturer's instructions and we selected the $\Delta \mathrm{Rn}$ in the exponential phase of amplification plots to determine the $\mathrm{Ct}$ values and to obtain the linearity of calibration curves.

PCR efficiencies were calculated with a relative standard curve derived from a four cDNA dilution series in triplicate and gave regression coefficients greater than 0.98 and efficiencies greater than $96 \%$. To normalize gene expression we amplified the housekeeping gene $A C T b$. The gene expression levels were calculated for each sample in triplicate after normalization against the housekeeping gene $(A C T b)$, using the relative fold expression differences [37].

\section{Statistical analysis}

Results were expressed as means \pm SD. The statistical analysis was assessed by one way and two way analysis of variance (ANOVA). In all analyses, a $P$-value less than $0.05(P<0.05)$ was considered a significant difference. Differences among groups yielding a statistical significance with $P<0.05$ were tested with Bonferroni as a post-hoc test. Statistical analyses were performed by using SPSS for Windows version 16.0 (SPSS Inc., Chicago, IL, USA). 


\section{Results}

\section{In vivo study}

\section{Histomorphometric effects of risedronate}

$\mathrm{BV} / \mathrm{TV}$ was higher in Ris treated groups with respect to GC and control groups. Accordingly, Ris-treated group showed higher Trabecular Thickness and Number and lower Trabecular Separation than GC and control groups (Table 1). In addition, Ris treated groups showed increased Wall Thickness, the end product of osteoblastic activity. As for turnover, we observed decreased Activation Frequency in Ris treated rats, confirming our previous findings [16].

\section{Effects of risedronate and glucocorticoids on osteocytic apoptosis}

According to Plotkin et al. [12], rats treated with GC showed a significant increase of apoptosis with respect to controls ( 86.4 vs $10.2 \%, P<0.001$, Figure 1 ), reduced by the addition of Ris.

\section{Effects of risedronate and glucocorticoids on osteocytic COX-2 expression}

We evaluated COX-2 expression in all rats. Rats treated with Ris showed an increased expression of osteocytic COX-2 vs placebo group (IHS: 7.8 vs $0.6, P<0.001$, Figure 2). On the contrary, rats treated with GC did not show any significant difference in COX-2 expression with respect to placebo.

On the other hand, the combined treatment (GC and Ris) induced a significant increase of COX-2 expression with respect to the placebo (IHS: 4.8 vs $0.6, P<0.001$ ), even if significantly lower than Ris alone treated group (IHS: 4.8 vs $7.8, P<0.001)$. Furthermore, increased COX-2 gene expression observed with Ris was maintained even in the presence of GC, suggesting that Ris counteracts negative effects of GC on osteoblastic lineage.

\section{In vitro study}

\section{Effects of risedronate on cell viability}

We evaluated, using bone marrow stromal cells and MLO-y4 osteocytes, the effect of Ris at concentrations of $0,0.1$ to $10 \mu \mathrm{M}$ with or without COX-2 inhibitor NS$398(0.1 \mu \mathrm{M})$ after three days of culture. The increased levels of cell viability obtained by XTT test at different concentrations of Ris are reported in Figure 3a. This effect could be associated with an increased proliferation and/or survival of cells. Nevertheless, when we inhibited the COX-2 pathway using NS-398, the effect of Ris on cell viability was significantly reduced, at least at the highest concentrations. We also evaluated cell viability in bone marrow stromal cells and MLO-y4 osteocytes treated with dexametasone with or without risedronate. Our results in bone marrow stromal cells (Figure 3b) showed that Ris reduces the negative effect on viability induced by dexametasone in a dose dependent manner. In addition, we observed similar results in the MLO-y4 osteocytes (Figure 4). Also in MLO-y4, the addition of NS-398 reduced the cell viability increased by Ris. This effect was significant at the highest concentration of Ris (Figure 4).

\section{Effects of risedronate on gene expression}

RT Real Time PCR analysis was carried out to assess the expression of $C O X-2$ and bone marker Alkaline Phosphatase $(b-A L P)$ genes in bone marrow stromal cells and MLO-y4 osteocytes. In bone marrow stromal cells, after $72 \mathrm{~h}$ of Ris treatment, the expression of genes coding for $C O X-2$ and $b-A L P$ were upregulated in a dose dependent manner (Figure $5 \mathrm{a}, \mathrm{c}$ ). To test the effect of $C O X-2$ in terms of response to Ris treatment, the cultures were treated with or without the NS-398. We observed a significant decrease in $b$ - $A L P$ gene expression (and obviously in $C O X-2$ gene expression) in cells

Table 1 Histomorphometric results in rats treated with glucocorticoids (GC) and risedronate (Ris)

\begin{tabular}{|c|c|c|c|c|}
\hline & Controls & Ris & GC & GC+Ris \\
\hline Bone volume/tissue volume (\%) & $35 \pm 1$ & $39 \pm 1(b, c)$ & $31 \pm 1(b)$ & $36 \pm 1(a)$ \\
\hline Trabecular thickness $(\mu \mathrm{m})$ & $50 \pm 1$ & $55 \pm 1(b)$ & $43 \pm 1(b)$ & $53 \pm 1(a)$ \\
\hline Trabecular number (N/mm) & $3.4 \pm 0.2$ & $4.6 \pm 0.1(b)$ & $2.9 \pm 0.1(b)$ & $4.4 \pm 0.1(a, b)$ \\
\hline Trabecular separation ( $\mu m)$ & $155 \pm 6.5$ & $139 \pm 4.8(b, c)$ & $273 \pm 5.3(b)$ & $144 \pm 6.1(\mathrm{a})$ \\
\hline Mineral apposition rate ( $\mu \mathrm{m} /$ day) & $0.66 \pm 0.04$ & $0.65 \pm 0.04$ & $0.62 \pm 0.05(b)$ & $0.65 \pm 0.04$ \\
\hline Mineralized surface/BS (\%) & $11.2 \pm 1.5$ & $9.8 \pm 0.9(b)$ & $9.6 \pm 0.9(b)$ & $9.8 \pm 1.0(b)$ \\
\hline Bone formation rate/BS $\left(\mu \mathrm{m}^{3} / \mu \mathrm{m}^{2} /\right.$ day & $7.4 \pm 1.2$ & $6.3 \pm 0.6(b)$ & $5.9 \pm 0.6(b)$ & $6.3 \pm 0.6(b)$ \\
\hline Wall thickness ( $\mu \mathrm{m})$ & $16.8 \pm 1.3$ & $24.9 \pm 3.6(b)$ & $12.0 \pm 3.1(b)$ & $22.8 \pm 5.9(a, b)$ \\
\hline Activation frequency (N/yr) & $1.6 \pm 0.3$ & $0.9 \pm 0.2(b)$ & $1.9 \pm 0.6$ & $1.0 \pm 0.3(a, b)$ \\
\hline Active formation period (days) & $25.4 \pm 2.0$ & $38.8 \pm 5.4(b)$ & $19.4 \pm 4.8$ & $35.3 \pm 9.3(a, b)$ \\
\hline Eroded surface/BS (\%) & $1.9 \pm 1.0$ & $1.7 \pm 0.7$ & $2.2 \pm 1.1$ & $1.9 \pm 1.1$ \\
\hline
\end{tabular}

$\mathrm{BS}$, bone surface.

a) $P<0.001$ vs GC. b) $P<0.05 / P<0.001$ vs controls. c) $P<0.001$ vs $G C+$ Ris.

All values are expressed as mean $\pm \mathrm{SD}$. 

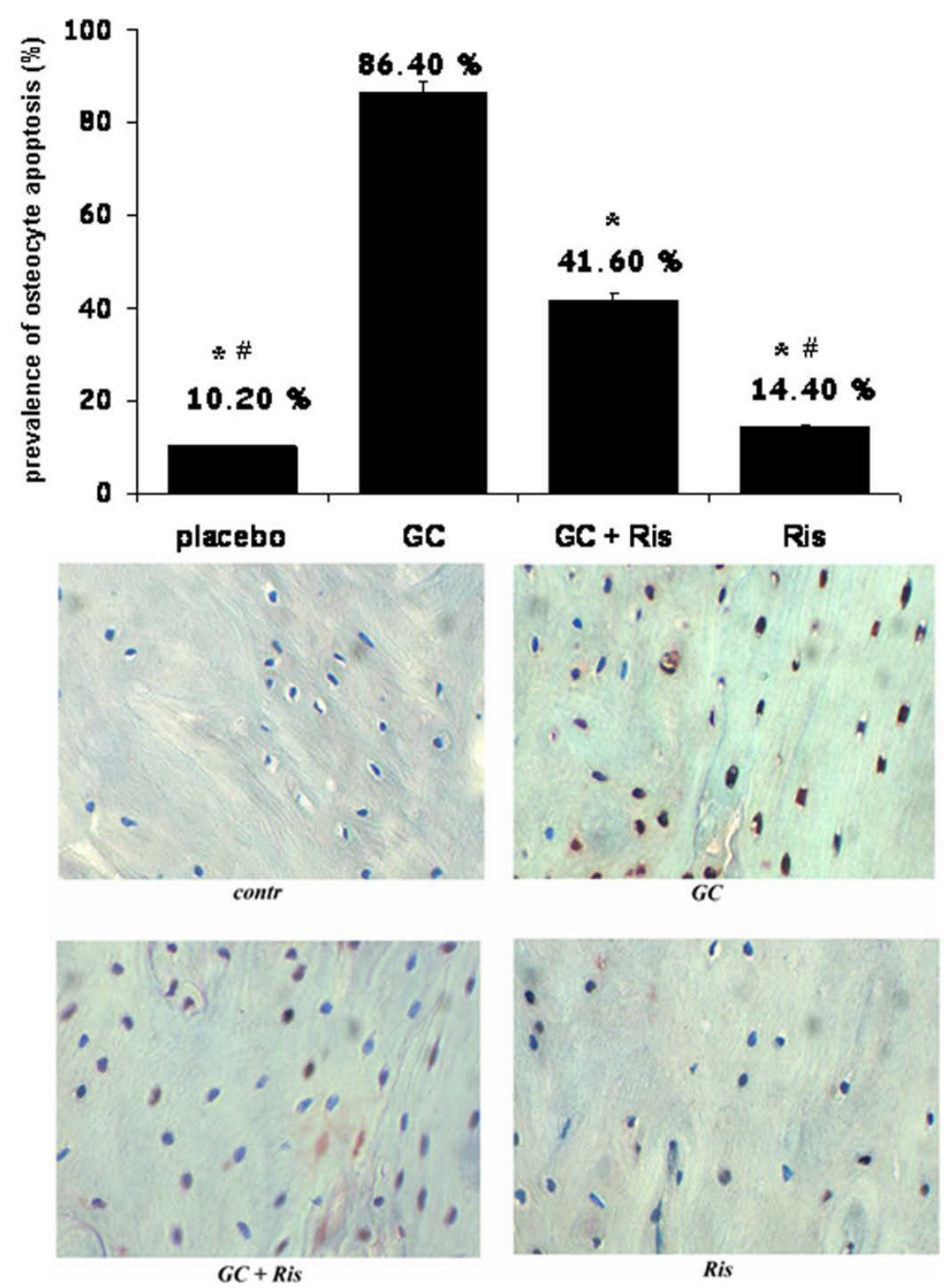

Figure 1 Osteocyte apoptosis (TUNEL) in rats treated with risedronate (Ris) and glucocorticoids (GC). TUNEL positive apoptotic cells with respect to total cells expressed as percentage were quantified in randomly selected six microscopic fields (200 $\mu \mathrm{m}$ square, each) under $40 \times$ magnification. * $P<0.001$ vs GC; $\# P<0.001$ vs GC + Ris.

treated with NS-398, confirming a reduced recruitment of stromal cells to osteoblastic lineage.

In addition, we evaluated the effect of glucocorticoid on $C O X-2$ expression in response to Ris. We found that Ris reduced the downregulation due to DEX in a dose dependent manner (Figure $5 \mathrm{~b}$ ). The same results we obtained in MLO-y4 osteocytes, after $72 \mathrm{~h}$ of Ris treatment (Figure 6a, b). The addition of NS-398 inhibitor decreased significantly the Ris-induced $C O X 2$ and $b$ - $A L P$ gene overexpression.

\section{Discussion}

Clinical trials highlighted that patients with postmenopausal osteoporosis treated long term with bisphosphonates show a continuous increase of bone density, an effect that might not be explained simply by the contraction of the remodeling space expected from the inhibition of bone resorption [6,38-40].

Our histomorphometric data show that the main effect of Ris on remodeling in glucocorticoid-induced osteoporosis is the prolonged lifespan of osteocytes, characterized by reduced Bone Formation Rate, activation frequency and prolonged active Formation Period associated with increased wall thickness, according to our previous results [16]. The inhibition of remodelling along with the increase of wall thickness supported the hypothesis of a direct effect of Ris on osteoblastic lineage.

Nevertheless, the active Formation Period is not a direct measurement of osteoblast lifespan and the 


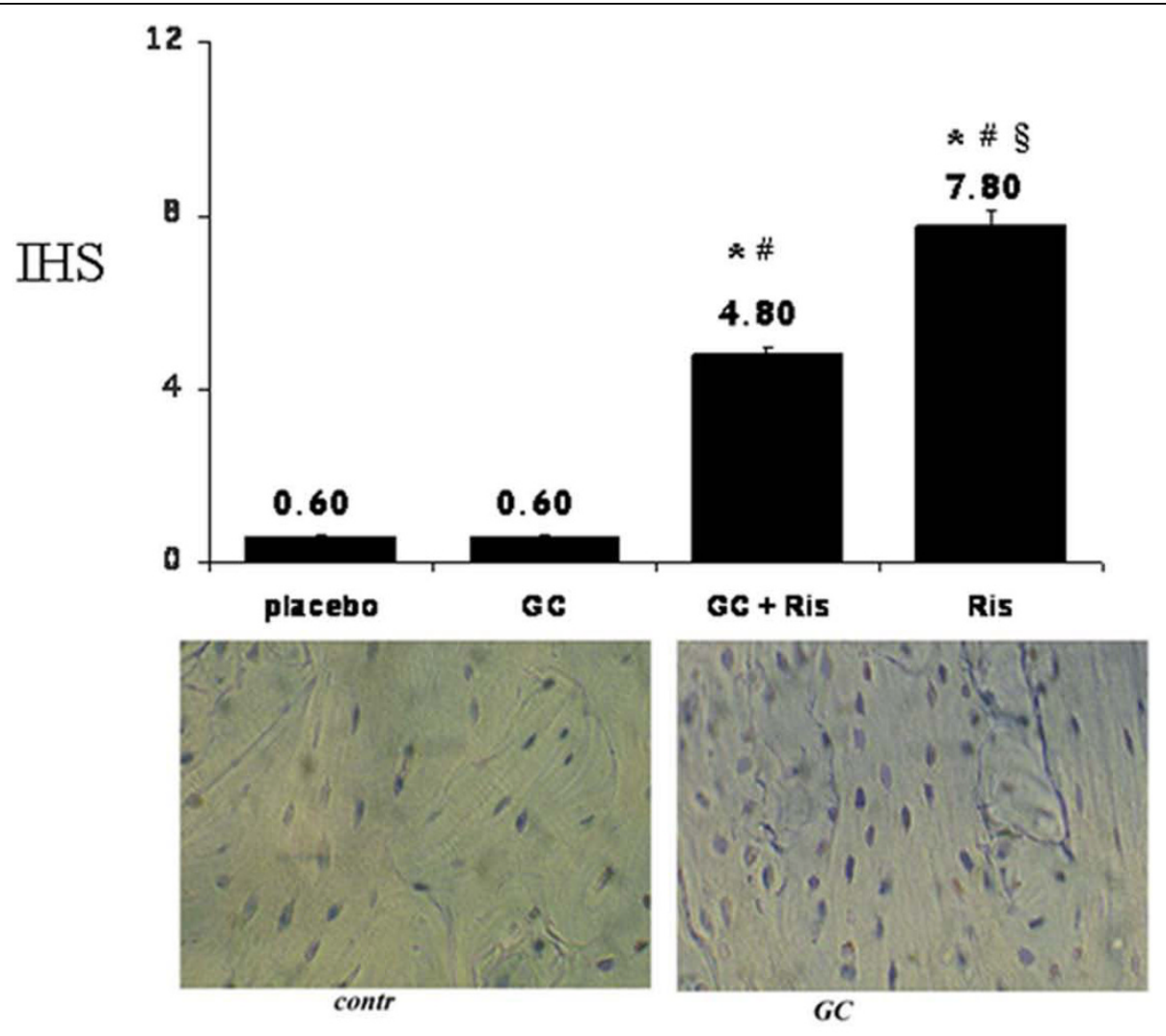

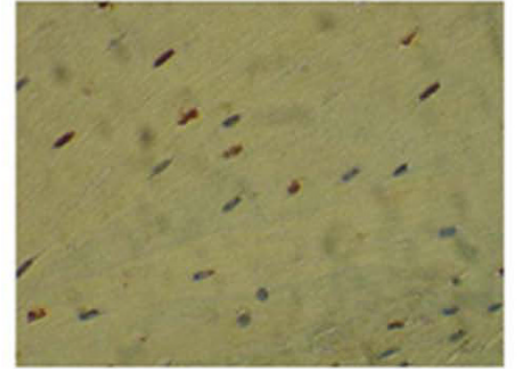

$G C+R i s$

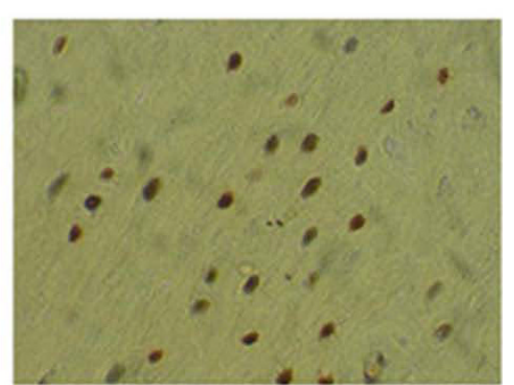

Ris

Figure 2 COX-2 expression in osteocytes of treated rats. COX-2 positive osteocytes in rats treated with risedronate (Ris) and glucocorticoids (GC). Results were expressed as Immuno-Hystochemical Score, IHS), based on German Immunoreactive. * $P<0.001$ vs controls; $\# P<0.001$ vs GC; $\S P<0.001$ vs GC+Ris.

increase observed could be due to a prolonged osteoblast precursor recruitment to individual bone remodeling units, resulting in a greater total number of osteoblasts, with no alteration to individual cellular lifespan. Thus, in this study we evaluated also osteocytic apoptosis to confirm a direct action of Ris in prolonging cell lifespan. We found that Ris prevents osteocyte apoptosis in GC-treated rats, according to previous findings by Plotkin et al. [12]. Even if the result confirms a positive effect of Ris on cell lifespan, this effect can not completely explain our histomorphometric data that showed an increased wall thickness, the end product of osteoblastic activity, also with respect to controls.
Accordingly, it has been suggested that bisphosphonate action on bone formation may contribute to the continuous positive balance leading to a more complete mineralization of bone tissue that was highlighted also in some clinical studies $[1,6,36,38]$. It is still unclear how bisphosphonates could stimulate directly bone formation, even if many metabolic pathways have been suggested: the stimulation of b-FGF [10] and of Bone Morphogenetic Protein -2 (BMP-2) [17], the upregulation of a cascade of osteoblast-related genes including $B M P-2, c b f a-1$, type 1 collagen and Bone Sialo-Proteins (BSP) [18], the influence on OPG/RANKL system [2]. In addition, earlier co-culture studies have shown that the presence of osteoblastic 


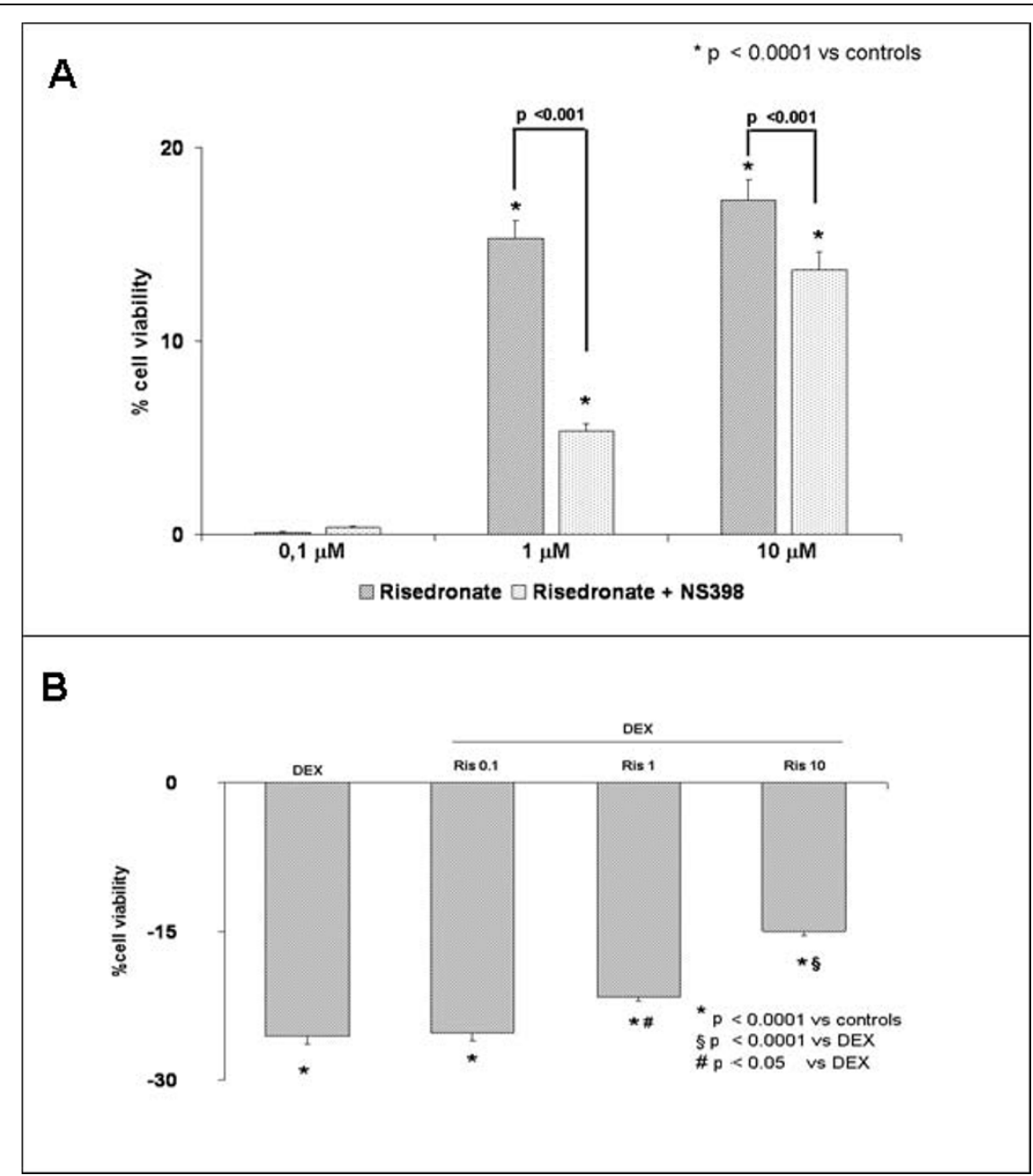

Figure 3 Viability values in bone marrow stromal cells. Difference of viability (XTT test) with respect to controls expressed in percentage in bone marrow stromal cells treated with risedronate (Ris) at different concentrations, with or without NS-398 COX-2 inhibitor (a) and with dexametasone $1 \mu \mathrm{M}(\mathrm{DEX})$ (b) with or without risedronate (Ris) at different concentrations. The experiments were performed in triplicate.

lineage cells is required also for a complete anti-resorptive effect of bisphosphonates, suggesting that these drugs inhibit osteoclast activity both directly, interfering with mevalonate pathway, but also indirectly trough osteoblast activation $[1,41]$. All these findings strengthen the concept that osteoblastic lineage is another important target of aminobisphosphonates.

Among all these different mechanisms of osteoblast activation, it is known that COX-2 and endogenous prostaglandins regulate bone formation and osteoblast differentiation in bone marrow stem cells (BMSCs) [42-44]. On the contrary, COX-2 disruption in BMSC cultures decreased osteoblastogenesis, and general cell growth and inhibit or delay fracture healing [45-47].

Since COX-2 are also involved in the early stage of bone marrow stem cell differentiation toward osteoblastic lineage [42], we may suppose that bisphosphonates influence osteoblastic lineage also by promoting osteoblast differentiation and viability at least in part through COX-2 pathway. This hypothesis is in agreement with recent data that confirm COX-2 as an important target of drugs used in metabolic bone diseases, such us strontium ranelate [30].

On the other hand, administration of a drug that inhibits COX-2 activity, such as non steroidal anti-inflammatory drugs (NSAIDs), seems to be associated with an inhibition of fracture healing and reduction of bone mineral density [29], even if it is unlikely that NSAIDs are able to block continuously all PG activity at the local level in vivo, since PGs work in an autocrine/paracrine manner and NSAIDs are generally given for short periods.

According to these findings, our results show an increased expression of $\mathrm{COX}-2$ in rat osteocytes treated with Ris and suggest that this pathway could be involved in the modulation of bone metabolism induced by 


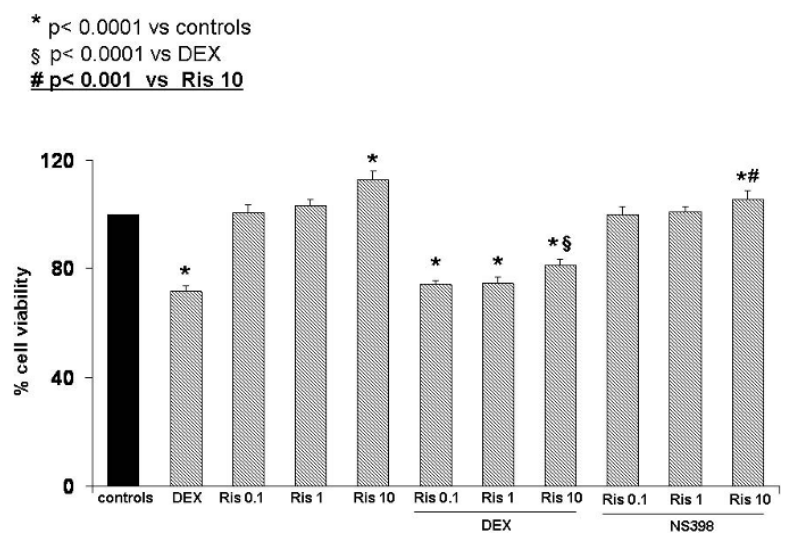

Figure 4 Viability values in MLO-y4 osteocyte cell line. Difference of viability (XTT test) expressed in percentage in MLO-y4 osteocytes treated with dexametasone $1 \mu \mathrm{M}(\mathrm{DEX})$, with or without risedronate (Ris) at different concentrations. In the right side of the figure are also reported the effects on viability of risedronate (Ris) at different concentrations with or without NS-398 COX-2 inhibitor. The addition of NS-398 limited cell viability increased by Ris. This effect was significant at the highest concentration of Ris. The experiments were performed in triplicate.

aminobisphosphonates. As already mentioned, we found that Ris treatment prolongs osteocyte lifespan, reducing their apoptosis induced by GC. Considering that COX-2 expression and PGs increase have been associated with higher resistance to apoptosis and tumour promotion in tissues other than bone [47], the reduced apoptosis and the higher expression of COX-2 could be strictly linked.

Moreover, Ris could have a potent influence on osteoblast precursors. This is a very intriguing aspect that suggests a positive effect of bisphosphonates both on the lifespan of osteoblastic lineage and on the recruitment of new cells inducing osteogenic differentiation of mesenchimal precursors. To confirm this hypothesis, we evaluated the effect of Ris at different concentrations on $C O X-2$ as well as on $b-A L P$ gene expression in vitro.

Alkaline phosphatase (ALP), a glycoprotein attached to the outer cell membrane by a glycosylphosphatidylinositol (GPI) anchor [48], exists as several isoenzymes and many isoforms present in tissues and serum. The $A L P$ gene at locus 2q34eq37 encodes the human intestinal isoenzyme of ALP whereas at locus 1p36ep34 encodes the human tissue-nonspecific ALP isoforms derived from bone, liver, and kidney [49]. In this study, we analyzed the RNA expression related to locus $1 \mathrm{p} 36 \mathrm{ep} 34$, so in the bone marrow environment our results are referred specifically to osteogenic lineage. This aspect is very important because, in this context, b-ALP may be considered a specific differentiation marker of osteoblastic precursors. The concomitant increased expression of $C O X-2$ and $b-A L P$ genes after treatment with Ris suggests a direct effect on osteogenic differentiation of mesenchymal precursors. This direct effect on osteoblastic lineage has been recently suggested also in another study in vitro, in which zoledronate induced sustained commitment of bone marrow derived mesenchymal stem cells for osteogenic differentiation [8]. To confirm the direct relationship between COX-2 increase and osteoblastic activity, we co-treated cells with a specific COX-2 inhibitor (NS-398), able to decrease the mRNA $C O X-2$ level [50], obtaining a concomitant significant decrease of $b-A L P$ and $C O X-2$ gene expression. However, the decreased $b A L P$ expression induced by NS-398 could be due also to the decreased viability of $b A L P$-expressing cells, in addition to the effect on reduced osteogenic differentiation of mesenchymal precursors.

In addition, we evaluated Ris effects on osteocyte cells in vitro, and we observed similar results obtained on osteoblasts. This implies that, in addition to an increased osteogenic recruitment, Ris is able to prolong the lifespan of osteogenic lineage mature cells. Also in this case, COX2 gene was involved as suggested by $b$ $A L P$ gene expression level in cells treated with Ris alone or in combination with NS-398 inhibitor. The ability of Ris to prevent negative GC effects observed on osteogenic precursors was confirmed also in MLO-Y4 osteocyte cells in agreement with our results in vivo.

These findings are of clinical relevance because they suggest a new mechanism through which bisphosphonates could exert their anabolic action on bone. The final result is a positive balance in bone turnover, characterized by an increased number of active osteoblastic/ osteocytic cells that have an important relevance in presence of bone diseases affecting osteoblastic lineage such as glucocorticoid-induced osteoporosis. In addition, this is the first study showing a direct effect of Ris on osteocytes through the upregulation of $\mathrm{COX}-2$ gene expression.

\section{Conclusions}

In this study, we confirmed that osteocytes could be stimulated by aminobisphosphonates. Considering the role of osteocytes in maintaining the bone matrix network and in regulating bone metabolism for correct bone homeostasis, the effect of aminobisphosphonates on these cells is very interesting. However, further studies are needed to elucidate the effective action of drugs on these cells.

Moreover, COX-2 expression is significantly increased in osteocytes and in bone marrow cells after Ris treatment. These results suggest COX-2 as an important target of Ris and support the hypothesis that aminobisphosphonates may have an anabolic effect on bone by increasing both the lifespan and the number of active osteogenic cells. 


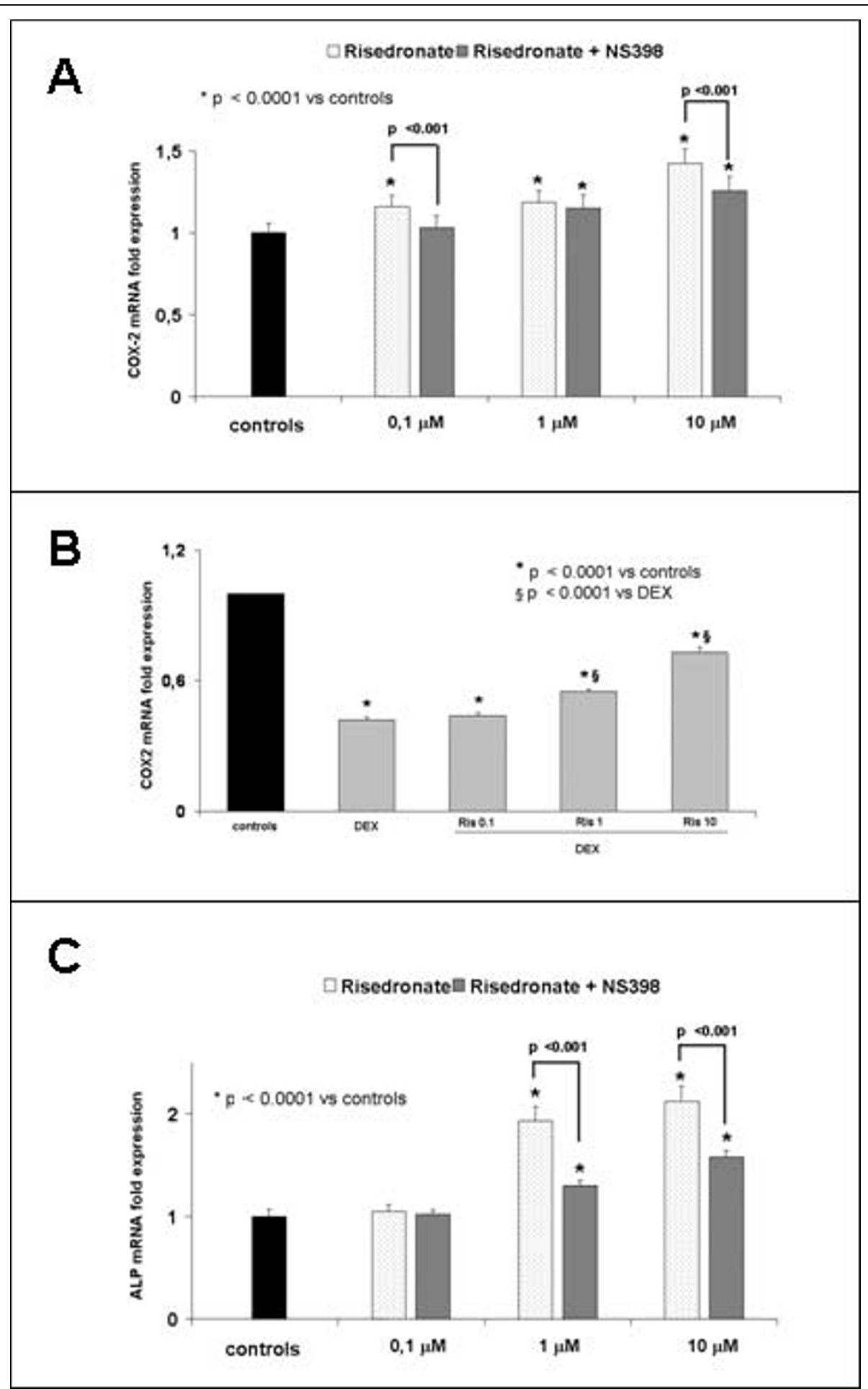

Figure 5 COX-2 and $\boldsymbol{b}$-ALP gene expression in treated bone stromal cells. (a) COX-2 gene expression of bone marrow stromal cells treated with risedronate (Ris) at different concentrations (0.1 to $10 \mu \mathrm{M})$ in presence or absence of NS-398 COX-2 inhibitor. Note that Ris induces significant COX-2 expression in a dose dependent manner. (b) COX-2 gene expression of bone marrow stromal cells treated with risedronate (Ris) at different concentrations $(0.1$ to $10 \mu \mathrm{M})$ in presence of dexametasone $1 \mu \mathrm{M}(\mathrm{DEX})$. (c) bALP gene expression of bone marrow stromal cells treated with risedronate (Ris) at different concentrations in presence or absence of NS-398 COX-2 inhibitor. The experiments were performed in triplicate. 


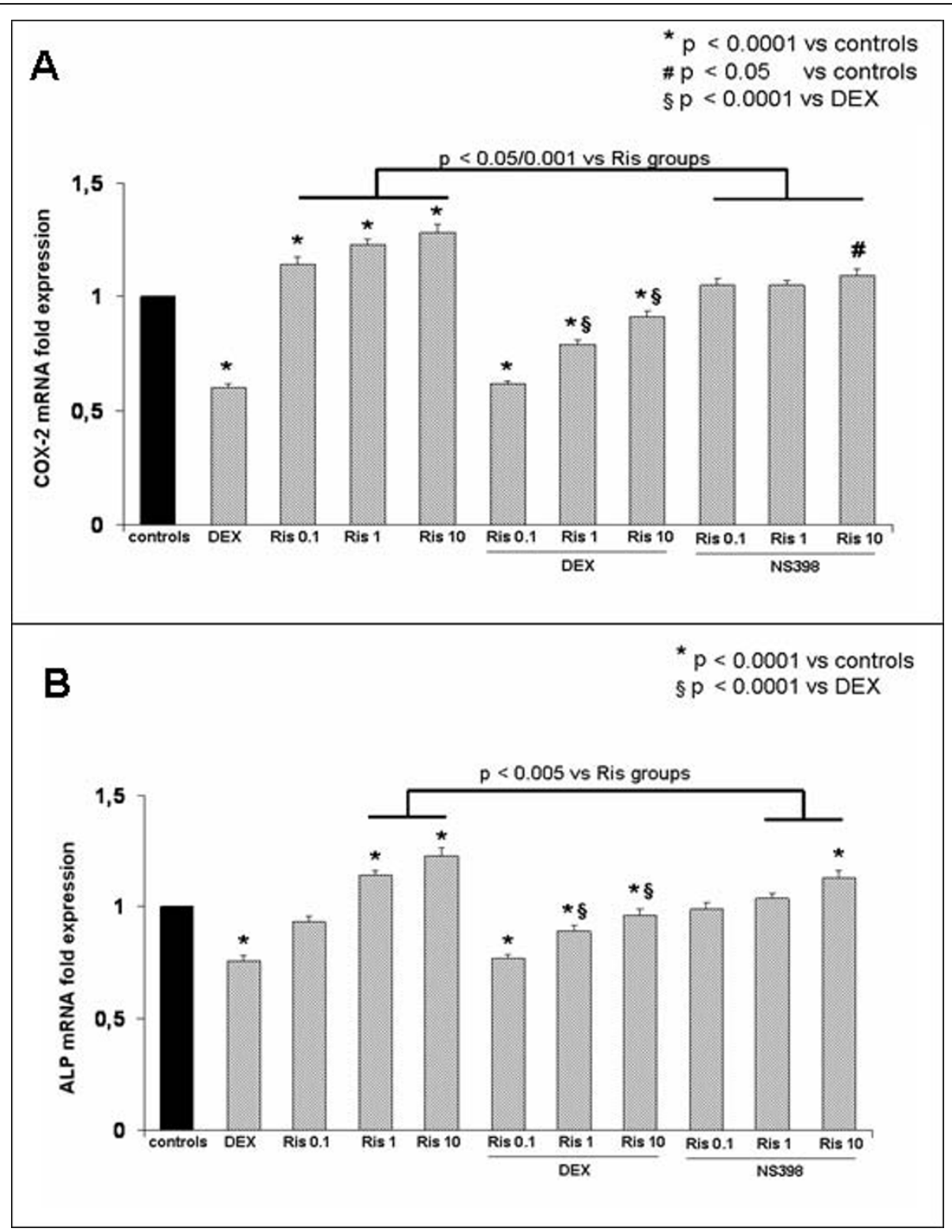

Figure 6 COX-2 and b-ALP gene expression in treated MLO-y4 osteocyte cell line. COX-2 (a) and b-ALP (b) gene expression in MLO-y4 osteocytes treated with dexametasone $1 \mu \mathrm{M}$ (DEX), with or without risedronate (Ris) at different concentrations. In the right side of the figure are also reported the effects on gene expression of risedronate (Ris) at different concentrations with or without NS-398 COX-2 inhibitor. Risedronate upregulated the gene expression in a dose dependant manner and reduced the downregulation of gene expression induced by dexametasone. The addition of NS-398 inhibitor significantly reduced the expression of COX-2 $(P<0.05 / 0.001)$ and $b-A L P(P<0.005)$ increased by Ris. The experiments were performed in triplicate.

\section{Abbreviations}

$\alpha$-MEM: $\alpha$-minimum essential medium; ACTB: b-actin; AEC: 3-amino-9-ethylcarbazole; B-ALP: bone alkaline phosphatase; BMD: bone mineral density; BMP-2: bone morphogenetic protein-2; BMSCS: bone marrow stem cells; BMU: basic multicellular unit; BPS: bisphosphonates; BSP: bone sialo-proteins; COX: cyclooxygenase; GC: glucorticoid; GPI: glycosylphosphatidylinositol; HIS: immunohistochemical score; NSAIDS: nonsteroidal anti-inflammatory drugs; PBS: phosphate-buffered saline; PGS: prostaglandins; RIS: risedronate; TUNEL: Transferase-Biotin-dUTP nick end labeling.

\section{Acknowledgements}

The authors thank Dr. L. F. Bonewald and Dr. Jennifer Rosser for kindly providing MLO-y4 osteocytes.

The authors also thank Procter \& Gamble Pharmaceuticals for providing risedronate and supporting the work. Funding resources were devoted to purchasing animals, chemical reagents and molecular primers and probes. The Sponsor was not involved in the study design, data collection, or analysis and interpretation of the data, and had no influence on the publishing of the data. 


\section{Author details}

${ }^{1}$ Clinic of Internal Medicine D, Department of Medicine - University of Verona Piazzale L. Scuro, 10 - 37134 Verona, Italy. ${ }^{2}$ 1st Medical Clinic, Department of Medical and Surgical Sciences, University of Padova - Via Giustiniani, 2 - 35128 Padova, Italy.

\section{Authors' contributions}

MTV, SG and LDC were responsible for the study design. MTV, FB and SS performed animal experiments. $L D$ and $M Z$ performed in vitro experiments. LDC performed histomorphometric and statistical analyses. MTV, EO, VLC and GR were responsible for manuscript preparation.

\section{Competing interests}

The authors declare that they have no competing interests.

Received: 22 January 2010 Revised: 2 August 2010

Accepted: 25 August 2010 Published: 25 August 2010

\section{References}

1. Russell RG, Xia Z, Dunford JE, Oppermann U, Kwaasi A, Hulley PA, Kavanagh KL, Triffitt JT, Lundy MW, Phipps RJ, Barnett BL, Coxon FP, Rogers MJ, Watts NB, Ebetino FH: Bisphosphonates: an update on mechanisms of action and how these relate to clinical efficacy. Ann $N$ Y Acad Sci 2007, 1117:209-257.

2. Viereck V, Emons G, Lauck V, Frosch $\mathrm{KH}$, Blaschke S, Gründker C, Hofbauer LC: Bisphosphonates pamidronate and zoledronic acid stimulate osteoprotegerin production by primary human osteoblasts. Biochem Biophys Res Comm 2002, 291:680-686.

3. Follet H, Li J, Phipps RJ, Hui S, Condon K, Burr DB: Risedronate and alendronate suppress osteocyte apoptosis following cyclic fatigue loading. Bone 2007, 40:1172-1177.

4. Storm T, Steinichw T, Thamsborg G, Melsen F: Changes in bone histomorphometry after long-term treatment with intermittent cyclic etidronate for postmenopausal osteoporosis. J Bone Miner Res 1993, 8:199-208.

5. Sato M, Grasser W, Endo N, Akins R, Simmons H, Thompson DD, Golub E, Rodan GA: Bisphosphonate action. Alendronate localization in rat bone and effects on osteclast ultrastructure. J Clin Invest 1991, 88:2095-2105.

6. Bone HG, Hosking D, Devogelaer JP, Tucci JR, Emkey RD, Tonino RP, Rodriguez-Portales JA, Downs RW, Gupta J, Santora AC, Liberman UA, Alendronate Phase III Osteoporosis Treatment Study Group: Ten years experience with alendronate for osteoporosis in postmenopausal women. N Eng J Med 2004, 350:1189-1199.

7. Reinholz GG, Getz B, Pederson L, Sanders ES, Subramaniam M, Ingle JN Spelsberg TC: Bisphosphonates directly regulate cell proliferation, differentiation, and gene expression in human osteoblasts. Cancer Res 2000, 60:6001-6007.

8. Ebert R, Zeck S, Krug R, Meissner-Weigl J, Schneider D, Seefried L, Eulert J, Jakob F: Pulse treatment with zoledronic acid causes sustained commitment of bone marrow derived mesenchymal stem cells for osteogenic differentiation. Bone 2009, 44:858-864.

9. Giuliani N, Pedrazzoni M, Passeri G, Girasole G: Bisphosphonates inhibit IL6 production by human osteoblastlike cells. Scand J Rheum 1998, 27:38-41.

10. Giuliani N, Pedrazzoni M, Negri G, Passeri G, Impicciatore M, Girasole G: Bisphosphonates stimulate formation of osteoblast precursors and mineralized nodules in murine and human bone marrow cultures in vitro and promote early osteoblastogenesis in young and aged mice in vivo. Bone 1998, 22:455-461.

11. Von Knoch F, Jaquiery C, Kowalsky M, Schaeren S, Alabre C, Martin I, Rubash HE, Shanbhag AS: Effects of bisphosphonates on proliferation and osteoblast differentiation of human bone marrow stromal cells. Biomaterials 2005, 26:6941-6949.

12. Plotkin LI, Weinstein RS, Parfitt AM, Roberson PK, Manolagas SC, Bellido T: Prevention of osteocyte and osteoblast apoptosis by bisphosphonates and calcitonin. J Clin Invest 1999, 104:1363-1374.

13. Marotti C, Palumbo G: The mechanism of transduction of mechanical strains into biological signals at the bone cellular level. Eur J Histochem 2007, 51(Suppl 1):15-19.
14. Burger EH, Klein-Nulend J, van der Plas A, Nijweide PJ: Function of osteocytes in bone-their role in mechanotransduction. J Nutr 1995, 125:2020S-2023S.

15. Peel NF, Moore DJ, Barrington NA, Bax DE, Eastell R: Risk of vertebral fracture and relationship to bone mineral density in steroid treated rheumatoid arthritis. Ann Rheum Dis 1995, 54:801-806.

16. Dalle Carbonare L, Bertoldo F, Valenti MT, Zordan S, Sella S, Fassina A, Turco G, Realdi G, Lo Cascio V, Giannini S: Risedronate prevents the loss of microarchitecture in glucocorticoid-induced osteoporosis in rats. $J$ Endocrinol Invest 2007, 30:739-746.

17. Mundy G, Garret R, Harris S, Chan J, Chen D, Rossini G, Boyce B, Zhao M, Gutierrez G: Stimulation of bone formation in vitro and in rodents by statins. Science 1999, 286:1946-1949.

18. Im Gl, Qureshi SA, Kenney J, Rubash HE, Shanbhag AS: Osteoblast proliferation and maturation by bisphosphonates. Biomaterials 2004 25:4105-4115.

19. Koshishara Y, Kawamura M: Prostaglandins D2 stimulates calcification of human osteoblast cells. Biochem Biophys Res Comm 1989, 159:1206-1212.

20. Tasaki Y, Takamori R, Koshihara Y: Prostaglandins D2 metabolite stimulates collagen synthesis by human osteoblasts during calcification. Prostaglandins 1991, 41:303-313.

21. Gronowicz GA, Fall PM, Raisz LG: Prostaglandin E2 stimulates preosteoblast replication: an autoradiographic study in cultured fetal rat calvariae. Exp Cell Res 1994, 212:314-320.

22. Scutt A, Bertram P: Bone marrow cells are targets for the anabolic actions of prostaglandin E2 on bone: induction of a transition from nonadherent to adherent osteoblast precursors. J Bone Miner Res 1995, 10:474-487.

23. Scutt A, Bertram P, Brautigam M: The role of glucocorticoid and prostaglandins E2 in the recruitment of bone marrow mesenchymal cells to the osteoblastic lineage: positive and negative effects. Calcif Tissue Int 1996, 59:154-162.

24. Smith WL, Song I: The enzymology of prostaglandin endoperoxide $\mathrm{H}$ synthases-1 and -2. Prostaglandins Other Lipid Mediat 2002, 68-69:115-128.

25. Herschman HR, Xie W, Reddy S: Inflammation, reproduction, cancer and all that. The regulation and role of the inducible prostaglandin synthase. BioEssays 1995, 17:1031-1037.

26. Botting R, Ayoub SS: COX-3 and the mechanism of action of paracetamol/acetaminophen. Prostag Leukot Essent. Prostaglandins Leukot Essent Fatty Acids 2005, 72:85-87.

27. Kis B, Snipes JA, Busija DW: Acetaminophen and the cycloxigenase-3 puzzle: sorting out fact, fictions and uncertainties. J Pharmacol Exp Ther 2005, 315:1-7.

28. Li J, Burr DB, Turner CH: Suppression of prostaglandins synthesis with NS398 has different effects on endocortical and periostal bone formation induced by mechanical loading. Calcif Tissue Int 2002, 70:320-329.

29. Simon AM, Manigrasso MB, O'Connor JP: Cyclooxygenase 2 function is essential for bone fracture healing. J Bone Miner Res 2002, 17:963-976.

30. Choudhary S, Wadhawa S, Raisz LG, Alander C, Pilbeam CC: Extracellular calcium is a potent inducer of cyclooxygenase 2 in murine osteoblasts through an ERK signalling pathway. J Bone Miner Res 2003, 18:1813-1824.

31. Choudhary S, Halbout P, Alander C, Raisz L, Pilbeam C: Strontium ranelate promotes osteoblastic differentiation and mineralization of murine bone marrow stromal cells: involvement of prostaglandins. J Bone Miner Res 2007, 22:1002-1010.

32. Pilbeam C, Fall PM, Alander CB, Raisz LG: Differential effects of nonsteroidal anti-inflammatory drugs on constitutive and inducible prostaglandin G/H synthase in cultured bone cells. J Bone Miner Res 1997, 12:1198-203.

33. Kimmel DB: Quantitative histologic changes in the proximal tibial growth cartilage of aged female rats. Cells Materials 1991, Suppl 1: 11-18.

34. Parfitt AM, Drezner MK, Glorieux FH, Kanis JA, Malluche H, Meunier PJ, Ott SM, Recker RR: Bone histomorphometry: standardization of nomenclature, symbols, and units. J Bone Miner Res 1987, 2:595-610.

35. Fortier C, Barbeau J, Deslauriers N: Mast cells in the murine oral mucosa are of the connective tissue-type. Reg Immunol 1990, 3:35-41.

36. Kato Y, Windle JJ, Koop BA, Mundy GR, Bonewald LF: Establishment of an osteocyte-like cell line, MLO-Y4. J Bone Miner Res 1997, 12:2014-2023.

37. Heid CA, Stevens J, Livak KJ, Williams PM: Real time quantitative PCR Genome Res 1996, 6:986-994. 
38. Liberman UA, Weiss SR, Broll J, Minne HW, Quan H, Bell NH, RodriguezPortales J, Downs RW Jr, Dequeker J, Favus M: Effect of oral alendronate on bone mineral density and the incidence of fractures in postmenopausal osteoporosis. N Engl J Med 1995, 333:1437-1443.

39. Black DM, Cummings SR, Karpf DB, Cauley JA, Thompson DE, Nevitt MC, Bauer DC, Genant HK, Haskell WL, Marcus R, Ott SM, Torner JC, Quandt SA, Reiss TF, Ensrud KE: Randomised trial of effect of alendronate on risk of fracture in women with existing vertebral fractures. Lancet 1996, 348:1535-1541.

40. Mortensen L, Charles P, Bekker PJ, Digennaro J, Johnston CC Jr: Risedronate increases bone mass in an early postmenopausal population: two years of treatment plus one year of follow-up. J Clin Endocrinol Metab 1998, 83:396-402.

41. Sahni M, Guenther HL, Fleisch H, Collin P, Martin TJ: Bisphosphonates act on rat bone resorption through the mediation of osteoblasts. J Clin Invest 1993, 91:2004-2011.

42. Flanagan AM, Chambers TJ: Stimulation of bone nodule formation in vitro by prostaglandins E1 and E2. Endocrinology 1992, 130:443-448.

43. Ueda K, Saito A, Nakano H, Aoshima M, Yokota M, Muraoka R, Iwaya T: Cortical hyperostosis following long-term administration of prostaglandins E1 in infants with cyanotic heart disease. J Pediatr 1980, 97:834-836.

44. Norrdin RW, Shih MS: Systemic effects of prostaglandin E2 on vertebral trabecular remodelling in beagles used in a healing study. Calcif Tissue Int 1988, 42:363-368.

45. Zhang X, Schwarz EM, Young DA, Puzas JE, Rosier RN, O'Keefe RJ: Cyclooxygenase-2 regulates mesenchymal cell differentiation into the osteoblast lineageand is critically involved in bone repair. J Clin Invest 2002, 109:1405-1415.

46. Naik AA, Xie C, Zuscik MJ, Kingsley P, Schwarz EM, Awad H, Guldberg R, Drissi H, Puzas JE, Boyce B, Zhang X, O'Keefe RJ: Reduced COX-2 expression in aged mice $s$ associated with impaired fracture healing. J Bone Miner Res 2009, 24:251-264.

47. Trifan OC, Hla T: Cyclooxygenase-2 modulates cellular growth and promotes tumorigenesis. J Cell Mol Med 2003, 7:207-222.

48. Lauc G, Heffer-Lauc M: Shedding and uptake of gangliosides and glycosylphosphatidylinositol-anchored proteins. Biochim Biophys Acta 2006, 1760:584-602.

49. Fishman WH: Alkaline phosphatase isozymes: recent progress. Clin Biochem 1990, 23:99-104.

50. Liu JF, Zhu GJ, Jamieson GG, Wu TC, Zhu TN, Shan BE, Drew PA: NS-398 induces apoptosis in human esophageal cancer cells through inhibition of NF-kappaB downstream regulation of cyclooxygenase-2. Cancer Invest 2009, 27:17-23.

\section{doi:10.1186/ar3122}

Cite this article as: Valenti et al:: The effect of risedronate on osteogenic lineage is mediated by cyclooxygenase-2 gene upregulation. Arthritis Research \& Therapy 2010 12:R163.

\section{Submit your next manuscript to BioMed Central and take full advantage of:}

- Convenient online submission

- Thorough peer review

- No space constraints or color figure charges

- Immediate publication on acceptance

- Inclusion in PubMed, CAS, Scopus and Google Scholar

- Research which is freely available for redistribution

Submit your manuscript at www.biomedcentral.com/submit
C Biomed Central 